\title{
Reading Logs and Literature Teaching Models in English Language Teacher Education
}

\section{Diarios de lectura y modelos de enseñanza de la literatura en la formación docente en inglés ${ }^{*}$}

\author{
Ornella Ochoa Delarriva \\ Enrique Alejandro Basabe \\ leng_ext@ffchst.unlpam.edu.ar
}

Universidad Nacional de La Pampa, Santa Rosa, Argentina

Reading logs are regularly used in foreign language education since they are not only critical in the development of reading comprehension but may also be instrumental in taking readers beyond the referential into the representational realms of language. In this paper we offer the results of a qualitative analysis of a series of reading logs written by advanced students for a literature course in an English language teacher education program in Argentina. The logs were coded according to the different literature teaching models followed in the program, which let us ponder on the applicability and usefulness of reading logs, and on the need to promote diversity in literature teaching in English language teacher education.

Key words: English language teacher education, English literature teaching, reading comprehension, reading logs.

Los diarios de lectura suelen ser usados en la enseñanza de una lengua extranjera para el desarrollo no sólo de la comprensión lectora sino también de los usos representacionales del lenguaje. En este trabajo ofrecemos los resultados de un análisis cualitativo de una serie de diarios de lectura compuestos por estudiantes de un nivel avanzado de inglés en un programa de formación docente en Argentina. Éstos fueron codificados en función de los distintos modelos de enseñanza de la literatura seguidos en el programa, lo que nos permitió una reflexión sobre la aplicabilidad de los diarios de lectura y sobre la necesidad de diversidad en la enseñanza de la literatura en la formación docente del profesorado en inglés.

* Received: January 30, 2015. Accepted: July 18, 2015.

How to cite this article (APA $6^{\text {th }}$ ed.):

Ochoa Delarriva, O., \& Basabe, E. A. (2015). Reading logs and literature teaching models in English language teacher education. $\mathrm{HOW}, 22(2), 37-53$.

This article is licensed under a Creative Commons Attribution-NonCommercial-NoDerivatives 4.0 International License. License Deed can be consulted at http://creativecommons.org/licenses/by-nc-nd/4.0/. 
Palabras clave: compresión lectora, diarios de lectura, enseñanza de literatura inglesa, formación docente en inglés.

\section{Introduction}

Reading logs regularly accompany the development of reading comprehension in the early stages of English language learning. Likewise, the complex beginnings of teaching and research are frequently registered through various forms of teaching diaries and research journals. These, however, seldom record the intricacies of the reading process at advanced levels of English or the readers' responses to texts of a representational nature. With the latter lies the focus of this work. As teachers of English literature, we intend to foster in our students both aesthetic and personal responses, but, by the time they reach the course we teach, they have already acquired particular forms of acceptable reading to be related to the standard literature teaching models in use in English language teacher education; that is, the cultural model, the language model, and the personal growth model.

The aim of this article is to present the results of a small-scale experience with reading logs we carried out in 2012 in the context of the English literature course we teach at Universidad Nacional de La Pampa (UNLPam) in Argentina. The logs were examined following a qualitative methodology, and the results or our analysis were then read in light of recent literature trends in English language teaching (ELT). These are explored in our literature review, together with initial considerations on reading comprehension and the role of reading logs in it. In the subsequent sections, we describe the context of our research experience and the methodology we used for this particular experience, and we display the results or our data collection and analysis. Finally, we offer a discussion on the applicability and usefulness of reading logs in English language teacher education. We also ponder the chances that reading logs not only expand the cultural background of prospective teachers of English but also promote more linguistically and discursively informed readings, both of which positively inform the personal growth approach to the teaching of literature that we pursue.

\section{Literature Review}

In the last two decades, consensus has been reached to deem the foreign language reading process interactive (Eskey, 1988; Grabe, 1991) and to develop both top-down and bottom-up skills and strategies conjointly because both contribute to the successful comprehension of a text (Aebersold \& Field, 1997; Eskey \& Grabe, 1988). Claims have also been made to consider the social dimension of reading and encourage English language learners to detect the ideology of a text while in the process of identifying with, or becoming resistant to, its content (Spolsky, 1989; Wallace, 1995, 2005). Both interactive and critical approaches require close scrutiny of the texts on the part of the learners for deep and proficient reading 
comprehension. This, in turn, entails their involvement in reading as a critical active process integrating the various kinds of knowledge—-linguistic, social, or otherwise — with which they approach texts.

The case for reading literary texts has also been revisited and the activity reintegrated to ELT, not as a way of appropriating grammar and vocabulary or the moral values of a canon of great books, but with a greater emphasis on exploring the intertextual and intercultural relationships between different types of texts (Corbett, 2003; Montgomery, Durant, Fabb, Furniss, \& Mills, 2000). In the hope that literature "opens up, calls upon, stimulates, and uses areas of the mind, from imagination to emotion, from pleasure to pain," (McRae, 1991, p. 3), advanced students of English are encouraged to move beyond the sphere of referential language, that is, transaction-based acts through which they exchange information or handle a given social situation. Accordingly, they are expected to plunge into representational language, that is, that language provided by literature and other genres of popular culture (Elliot, 1990; Rosenblatt, 1985). Therefore, literature provides a wider frame not only of linguistic reference, but also for more challenging and involving types of processing than the generally circumscribed reading contexts of ELT have offered so far.

This statement about literature, however, should be approached cautiously because there have been fixed tendencies in its teaching that may not necessarily bring into play imaginative interaction and creative response. Carter and Long (1991) categorized those models as follows: (a) the cultural model, by which students are introduced to the canonical works produced by a particular nation over a historical period as a token of the moral and ideological values of that culture; (b) the language model, by which literature is used as an instrument for use in connection with the teaching of specific vocabulary and structures; and (c) the personal growth model, which does coincide with our previous point about reading literature as an engaging process that will generate lasting pleasure and deep satisfaction well beyond the literature course and throughout the students' lives.

These models, also supported by more recent classifications (Khatib, Rezaei, \& Derakhshan, 2011; Van, 2009), are not mutually exclusive, but we suggest that strong inclinations towards one or another have been noticeable in different areas of ELT. Our contention is that, in stark coincidence with the differing social contexts favoring either BANA (Britain, Australasia, and North America) or TESEP (tertiary, secondary, primary) methodologies (Holliday, 1994), the language model has prevailed in global textbooks aimed at bilingual schools in the private sector; whereas the dominance of the cultural model has seldom been discussed in English language teacher education. ${ }^{1}$

1 Broadly stated, BANA methodologies are the particular instrumental communicative approaches applied in language schools and private institutes, and TESEP refer to the contexts of state education, usually at the influence of wider educational policies and fewer resources (Holliday, 1994). 
In this paper, we display the results of a qualitative analysis of a series of reading logs written by advanced students of English for a literature course in an English language teacher education program in Argentina. Students enrolled in these programs have been acquainted with the narrative quality of dialogue journals and teaching diaries for some time (Bailey, 1990; Thornbury, 1991). Teaching journals have also been hailed as meditational tools in fostering teachers' professional development (Johnson \& Golombek, 2011). The use of research journals to demonstrate the complexity of concerns undergone by teacherresearchers has also been cogently described (Banegas, 2012). Reading logs share the quasi-narrative quality of these text types. However, although many students have reported positively on their usefulness (Shen, 2009) and that of dialogue journals (Barkhuizen, 1995; Denne-Bolton, 2013), reading logs in particular are seldom used in higher education, probably because it is assumed that students usually engage in personal note-taking without being required to do so.

Since the 1980s, advocates of a reader response approach to literature have continually hailed the use of reading logs in literature classes in ELT (Carlisle, 2000; Benton \& Fox, 1990; Rosenblatt, 1985). They constitute a while-reading activity that involves the organization of the reader's thoughts and feelings about the text, a process that is seen as both reflective and creative. The final document, the log, evidences each reader's response to the aesthetic event and his or her interactions with the perspectives in the literary work while in the process of creating meaning. Meaning in this context is always critical and self-constructed, and, therefore, diverse outcomes may result. This eventually reveals the multiple interpretations that can be produced for a text in a literature class.

The decision to include reading logs as part of the English literature course we teach at UNLPam in Argentina was taken in 2012. Our course was the last one in a series of three subjects devoted to the teaching of literature; so our advanced students were expected to have already acquired all the systemic and schematic knowledge required to read literary texts in their original versions. This, however, was not always the case, as we had observed through the years how they had struggled, for example, during their reading of Ondaatje's (1993) The English Patient. Therefore, we resolved to have our students write reading logs as a small-scale experience. We expected them to stay consistently focused during the reading process and move beyond literal understanding towards an aesthetic appreciation of literary texts. We were also convinced that the activity would encourage what Carlisle (2000) labeled "the intense personal nature of reading" (p. 14), which supported our intention of gradually adopting a personal growth approach to the teaching of literature. The students wrote their logs as they read the novel, and the personal reflections based on them informed our class discussions later. The results were truly varied, but they let us draw partial conclusions that might provide answers to our research question: Which type of models - cultural, linguistic, or personal— did students favor in the production of their reading logs? 


\section{Method}

\section{Setting}

The experience was carried out as part of the course on contemporary English literature we teach at UNLPam. English Literature II is a subject taught during the second term of the fourth year of the course of studies, and its corpus officially comprises the literature of the English-speaking countries in the 20th century. ELT is one of the four-year programs that can be followed at the Faculty of Human Sciences at the above-mentioned university in which about 150 students are enrolled. UNLPam is a medium-sized institution and the only state university in the province of La Pampa in central Argentina.

\section{Participants}

Fourteen students taking English Literature II were asked to write reading logs as they read Ondaatje's (1993) The English Patient. ${ }^{2}$ Thirteen of the students were female, and one was a male. All were approximately 20 to 23 years old. Although 20 students actually took the course in 2012, 14 chose to comply with the activity, and the remaining six engaged in longer and deeper discussions in the oral exams taking place at the end of the seminar. The students, who had a post-intermediate to advanced level of English, were provided with the guidelines to write a reading log that is included in Appendix 1. Their personal reflections were used for the class discussions on the novel under consideration.

\section{Procedure}

Data collection. Initially, there were two sources of data, both of which were documents: (a) the reading logs written by the students, and (b) their final self-assessment and their teachers' notes. The students wrote the logs at home during a period of 20 days in October and November in 2012 while they were reading the novel. The logs varied in length from five to 50 pages, and all of them were handwritten, except Logs 5 and 11, which were submitted electronically. Two logs were not used as part of the data; $\log 2$ was a personal reflection on the novel submitted by the student at the end of the course, and Log 13 was excessively long and personal, and so would have unbalanced our results.

2 The English Patient is a novel written by Sri Lankan/Canadian author Michael Ondaatje and published in 1993. Set in an Italian villa at the end of World War II, it follows the events in the life of a burnt man and the love triangle in which he gets involved during the North African campaigns in the 1930s. The novel won the Booker Prize and was made into a highly successful film, whose script was also written by Ondaatje. 
At first, we thought that including the students' self-assessments and their teachers' evaluations would result in additional findings that might inform our research because we considered that they constituted a different perspective on the activity from the logs themselves. Yet, most of the students' responses were reduced to moderate expressions of having accomplished the task, and we understood that considering the teachers' notes to the logs might become not only a somewhat redundant action, but also one that might become biased, given that the teacher was one of the researchers and authors of this study. In addition, unfortunately, there were no observations of class discussions on the basis of the logs; nor did we interview our students at the end of the course. As a result, the lack of these two resources constitutes a limitation to this paper in the sense that, apart from our analysis of the written documents, we do not have further elements to ensure validity and reliability.

Data analysis. In the descriptive stage of the study, the data sources were numbered in order to ensure anonymity, and they were coded following content analysis (Kvale, 2007). Thematic categories were drawn from Carter and Long's (1991) classification for literature teaching models, and consequently the data were sorted into three themes that we broadly labeled (a) cultural, (b), linguistic, and (c) personal. We considered that the first two roughly coincided with Hedge's (2000) arrangement of the types of knowledge involved in reading: schematic (general world, sociocultural, topic, and genre knowledge) and systemic (syntactic and morphological knowledge), respectively. Specifically speaking, the cultural model of literature teaching necessarily involves the reader's work on the literary texts with the particular aim of interpreting their meanings; whereas a language based approach to literature is usually more concerned with the act of decoding the language as a system in itself.

Then, we proceeded to code the log entries including all types of cultural references and those considering the linguistic aspects of the literary text, accordingly. We marked all of those plausible to be catalogued as personal responses in the same way. We excluded from our coding all ambiguous references, such as quotations without any clear labeling, lists of events in the narrative, summaries of chapters, and so forth. The categories for content analysis were highlighted in the sources of data under consideration. Comments were also made about any particular element that we deemed worth either explaining or expanding. We carried out this process separately, and at the explanatory level of analysis, a thorough comparative examination of both versions was attempted so as to guarantee peer checking and a clearly ordered rendering of the results (Gibbs, 2007).

\section{Results}

Carlisle's (2000) guidelines to write a reading log (Appendix 1) clearly call for a personal approach to the activity. The first six expected outcomes in the list included memories and reflections from personal experiences related to the literary text and thoughts and feelings 
stimulated by the characters and events in the story. Only the remaining three point at either a linguistic or a cultural model, since they ask readers to study how the story is being told and to find connections with other texts, ideas, and courses, respectively.

Table 1. Cultural, Linguistic, and Personal References in Reading Logs

\begin{tabular}{||c|c|c|c||}
\hline \multirow{2}{*}{ Log } & \multicolumn{3}{|c||}{ References } \\
\cline { 2 - 4 } & Cultural & Linguistic & Personal \\
\hline 1 & 9 & 0 & 3 \\
\hline 2 & 1 & 0 & 3 \\
\hline 3 & & & \\
\hline 4 & 11 & 2 & 0 \\
\hline 5 & 17 & 2 & 13 \\
\hline 6 & 8 & 15 & 8 \\
\hline 7 & 0 & 3 & 17 \\
\hline 8 & 0 & 5 & 5 \\
\hline 9 & 0 & 2 & 2 \\
\hline 10 & 10 & 0 & 2 \\
\hline 11 & 8 & 1 & 4 \\
\hline 12 & 3 & 0 & 13 \\
\hline 13 & & & 70 \\
\hline 14 & 17 & 0 & 0 \\
\hline Total & 84 & $\mathbf{3 0}$ & $\mathbf{7 0}$ \\
\hline
\end{tabular}

Our coding, however, revealed that in their reading logs our students showed a very strong tendency to consider issues that we labeled cultural. We marked 84 cases under this heading, which comprised explicit references to geography, history, art, or particular theoretical approaches to literature. Those constituted the vast majority in $\operatorname{Logs} 1,4,5,10$, and 14 , as can be seen in Table 1 . In most cases, students were inclined to quote a specific 
stretch of text and tag it using the technical terminology they had learnt in relationship with the phenomenon they noticed. The most recurrent labels were ethnocentrism, imperialism, religion, and art. One of the entries, for example, read: "Kirpal Singh: he's Indian but he's an English soldier = IMPERIALISM" ( $\log 4)$; another tried to explain Kip's leaving the Euro-American characters in the villa stating: "They are dead because they belong in a culture that is dead for him" $(\log 6) .^{3}$ A third student reflected on the role played by Katherine Clifton, stating: "It was strange that a woman was involved in an expedition since it was supposedly a man's undertaking. Societal norms. Separate spheres" $(\log 11) \cdot{ }^{4}$ Others concentrated on war as a theme and pondered on theorizations of their own, such as: "The end of war makes societies change and as a consequence individuals are not the same, either, ... and everyone has to adapt to new paradigms" ( $\log 12)$, or the conclusive statement: "If we can rationalize war, we can rationalize anything" (Log 5). Cultural references were thus the most persistent in the logs, displacing both notes on the linguistic forms of the novel and personal responses to it.

There were only 30 unambiguous references to issues we categorized linguistic in the reading logs under analysis. However, as shown in Table 1, 15 of those belong to Log 6, which signals a specific student's ability or tendency to reflect on language use. Under this heading, annotations on how the story was told were included. A group of students made explicit attempts at identifying the particular literary resources involved in each case and labeled them accordingly, as in the following instances:

The desert is itself personified. $(\log 9)$

Books: a recurrent motif? A symbol? (Log 12)

The war has destroyed the villa yet it is still standing. Maybe it shows death and rebirth after war. $(\log 8)$

In other cases, references were reduced to brief evaluative remarks after a quotation from the text. Examples of these are the following:

“At night, in the mountains around them, even by ten o' clock, only the earth is dark. Clear grey sky and the green hills." Nice image. ( $\log 4)$

"There are betrayals in war that are childlike compared with our human betrayals during peace." Nice and so true. (Log 6)

“Talkers seduce, direct us into corners." I like that. (Log 9)

3 Kirpal Singh, or Kip, is an Indian sapper trained in England. In a post-colonial reading of the novel, he would represent the colonized subject against the Euro-American colonizers, Hana, Caravaggio, and apparently the English patient.

4 Katherine Clifton is a British lady who is married to an expeditionary but who later becomes the English patient's lover. 
These evidenced the aesthetic pleasure our students felt while reading the novel, a reaction most probably provoked by the use of the language, especially in the first case. Even though in the remaining two cases an evaluative or even emotional response to the citations from the text might have been involved, there was little precision as regards the particular feelings involved or the linguistic sources that generated them, and the statements generally remained at the level of impressionistic remarks.

A third group of students detected several cases of what they labeled intertextuality. Under that broad tag, they included mentions of other literary works, such as The Bible or Herodotus' Histories. Even though intertextuality, as used in literary studies or in discourse analysis, encompasses a wide range of phenomena, such as clause negation, direct quotation, and allusion, the cases identified by our students were mostly reduced to the discovery of explicit lexico-grammatical cues, such as key settings or characters' names in the above-mentioned texts. Therefore, we decided to keep those under the label linguistic.

Finally, there were 60 references we identified as personal. Those cases prevailed in Logs 8 and 12, but, as displayed in Table 1, most students at some moment responded personally to the novel under consideration. Responses included personal opinion, impressions, and reflections on the characters and events in the story. The two female characters particularly caught the students' attention, perhaps due to the fact that most of them were female and felt a closer relationship with them. $\log 7$, for example, only traced Hana's development as a character, as the student showed a clear empathy towards her story. ${ }^{5}$ At the beginning, she stated, "I feel pity for Hana, she has lost her father in the war. She's so unprotected," and later she declared, "for Hana books became half of her world, as well as for me when I was a child" (Log 7). Katherine Clifton was the other female character that triggered the students' reactions. Moreover, they felt attracted to judge her action on strong moral grounds, as shown in the following opposing responses to and interpretations of her action, which were later used, with the students' permission, to activate the class discussion suggested in Appendix 2:

Within a month Katherine and the English patient became lovers. What a [expletive] she was!! She was on her honeymoon for God's sake! Damn you K.! (Log 12)

The most interesting character! She has a strong character and takes up her decisions.... She starts an extramarital relationship with the English patient. She is not a [expletive]! She is just disloyal to her husband. ... She seems to be the rational part of the irrational relationship because she can control her feelings in front of society. He cannot. He is madly jealous. (Log 5)

5 Hana is the Canadian nurse who remains in charge of the English patient when the war ends, meets an old friend and father figure, and starts a relationship with Kip, the Indian sapper. Yet, at the end of the novel, she is still alone and feels at a loss. 
Interestingly, the former is a response by the only male student in the class; the latter belongs to a female reader.

Responses to the way in which certain events unfolded throughout the novel were also personal, as in the commentaries "Kip's story: very thrilling!!! I get nervous and anxious when he is dismantling a bomb, even when I know he'll succeed... he he [as if smiling]" (Log 12), or "how boring is this chapter! [sic] Nothing of much importance :)" (Log 5).

There were also some contrasting remarks on the task of writing the log itself. Whereas one student stated, "I'm not fond of reading and then stopping to take down notes. I prefer, instead, to read the complete novel or piece of writing and get together with a partner and comment on it" ( $\log 7)$; another composed a very long letter to praise the activity and thank her teachers as it had helped her concentrate on details that otherwise would have remained unobserved. That was $\log 13$, the one we decided not to examine for this analysis, due to its length and the extreme personal nature of its data.

\section{Discussion}

As stated in the title and suggested by our first research question, we initially tried to find relationships between the type of models — cultural, linguistic, or personal— that our students favored in the production of their reading logs and the literature teaching models at use in the context of our research. Nevertheless, we must acknowledge that there is no clear evidence that supports the relationships we tentatively establish here and that, therefore, they have to be taken cautiously and as mere propositions to stimulate a much needed discussion on literature teaching in English language teacher education.

We described our practice as following a personal growth model of teaching literature, and the guidelines with which we provided our students to write their reading logs clearly showed that personal bent. However, the first trend emerging from our data is their firm reliance on a cultural reading of the literary text. As shown above, most of the notes in our students' logs refer to the geographical, historical, or artistic issues at play in the novel. This might be taken as a heavy dependence on referential language, even in English language teacher education, where reading contexts have become increasingly circumscribed to journalistic and theoretical prose and in which the role of literature and other representational uses of language has been significantly diminished. It must also be admitted that literature teaching in TESEP frameworks has also persistently followed a rigid cultural model tied to canonical readings of literature in a set chronological fashion, which has only recently become inclusive of the cross-cultural realities of ELT in other contexts. For a related study, one of our interviewees claimed to have been formed to read literature as if it were theory (Basabe \& Germani, 2014a), which attests to the consistency of our results. 
However, we would be unfair if we did not recognize that our students eventually became involved and actually responded with enthusiasm to the reading process. In fact, references labeled personal came second, but very close to those tagged cultural in our data. Our results, therefore, complement those of Carlisle (2000) and Denne-Bolton (2013), in that most students producing their reading logs enjoyed the space of expressing their ideas, feelings, and opinions in a relaxed way. Furthermore, they also seemed to have moved beyond referential language and finally entered the representational realm offered to them by the fictional world of the literary text, which is made evident by their engagement with some of the characters in the novel and their attempts at discerning the reasons for their actions. In accordance with Denne-Bolton (2013), we could affirm then that reading logs applied to literary texts constitute an appropriate activity for English learners, even at an advanced level, because it encourages them to move from sheer semantic understanding towards enhanced overall appreciation of literary texts they have usually rejected as difficult ones.

Yet, as demonstrated by our data, that personal reading was seldom supported by precise linguistic references or weighty metalinguistic reflections. In most cases, our students failed to notice the linguistic sources of their aesthetic enjoyment and their approach to the literary text was thus mostly impressionistic. In literature teaching in English language teacher education, this might have resulted from the gradual disuse of the basics of literary studies, that is, aspects of narrative, figures of speech, poetic forms, which used to be the core of literature courses long ago, and the ongoing inclusion of novel theoretical aspects, such as those derived from post-colonial literature, among others. In addition, it is oftentimes the students that experience that scarcity of systemic knowledge, a state also reported in a previous paper (Basabe \& Germani, 2014b) and that needs to be seriously considered. The language model calls for rigorous awareness and deep comprehension of the ways in which both referential and representational language work, which represent skills we might not be successfully providing in literature teaching in English language teacher education.

Last, most of our students reported positively on the usefulness of reading logs, especially when the literary text is a complex one, which confirms not only previous findings by Shen (2009) and Barkhuizen (1995) but also our initial intuition about their applicability at advanced levels of English.

\section{Teaching Implications}

Our students' persistence in noticing cultural issues when writing in their reading logs may be attributed to our equal proclivity to favor a cultural model in the teaching of literature in TESEP contexts. The use of reading logs at advanced levels of English following the guidelines suggested by a reader-response approach should balance that bias and make both teachers and students confidently aware of the endless potential of self- and co-constructed 
meaning. Nevertheless, once students regain the power to read literary texts from their personal perspectives, they could be gradually re-introduced to the intricacies of the language of literary texts and to its refinement in both texture and structure. If they can perceive the linguistic integrity of literature at an advanced level, we hope, they will be better qualified to teach English in the BANA contexts in which they are most likely to develop their professional careers. A diverse and inclusive use of the models available in English literature teaching, thus, needs to be not only be seriously considered but also strongly encouraged.

\section{Conclusion}

We can affirm that reading logs applied to literary texts constitute an appropriate activity for English language learners, even at an advanced level, because it urges them to move from sheer semantic understanding towards enhanced overall appreciation of literary texts that have sometimes been rejected as difficult ones or, in other words, from the mere referential use of language into the realm of its representational possibilities. Though personally powerful, however, writing reading logs should also be articulated with literature teaching models that aim at both expanding the cultural background of prospective teachers of English and promoting linguistically and discursively informed readings. Only in that way may we form English language teachers able to discover the representational potential of literature in order to craft not only personal, but also critical, responses to the world around us.

\section{References}

Aebersold, J. A., \& Field, M. L. (1997). From reader to reading teacher: Issues and strategies for second language classrooms. Cambridge, UK: Cambridge University Press.

Bailey, K. M. (1990). The use of diary studies in teacher education programs. In J. C. Richards \& D. Nunan (Eds.), Second language teacher education (pp. 215-226). Cambridge, UK: Cambridge University Press.

Banegas, D. L. (2012). Identity of teacher-researcher in collaborative action research: Concerns reflected in a research journal. PROFILE Issues in Teachers' Professional Development, 14(2), 29-43.

Barkhuizen, G. P. (1995). Dialogue journals in teacher education revisited. College ESL, 5(1), 22-35.

Basabe, E. A., \& Germani, M. G. (2014a, November). Growing critical: hacia la lectura crítica a partir de la literatura en el profesorado en inglés [Growing critical: Towards critical reading in English language teacher education]. Paper presented at the Fourth International Conference on Research and Practice in Language and Literature. Bariloche, Argentina.

Basabe, E. A., \& Germani, M. G. (2014b). Reading for life: The Critical Literacy and Literature Project at UNLPam (2013-2016). Argentinian Journal of Applied Linguistics, 2(1), 32-41.

Benton, M., \& Fox, G. (1990). Teaching literature. Oxford, UK: Oxford University Press.

Carlisle, A. (2000). Reading logs: An application of reader response theory in ELT. ELT Journal, 54(1), 12-19. http://dx.doi.org/10.1093/elt/54.1.12. 
Carter, R., \& Long, M. N. (1991). Teaching literature. Harlow, UK: Longman.

Corbett, J. (2003). An intercultural approach to English language teaching. Clevendon, UK: Multilingual Matters.

Denne-Bolton, S. (2013). The dialogue journal: A tool for building better writers. English Teaching Forum, 51(2), 2-11.

Elliot, R. (1990). Encouraging reader-response to literature in ESL situations. ELT Journal, 44(3), 191-198. http://dx.doi.org/10.1093/elt/44.3.191.

Eskey, D. E. (1988). Holding in the bottom: An interactive approach to the language problems of second language readers. In P. L. Carrel, J. Devine, \& D. E. Eskey (Eds.), Interactive approaches to second language reading (pp. 93-100). Cambridge, UK: Cambridge University Press. http://dx.doi.org/10.1017/CBO9781139524513.011.

Eskey, D. E., \& Grabe W. (1988). Interactive models for second language reading: Perspectives on instruction. In P. L Carrel, J. Devine, \& D. E. Eskey (Eds.), Interactive approaches to second language reading (pp. 223-238). Cambridge, UK: Cambridge University Press. http://dx.doi.org/ 10.1017/CBO9781139524513.022.

Gibbs, G. (2007). Analyzing qualitative data. London, UK: Sage.

Grabe, W. (1991). Current developments in second language reading research. TESOL Quarterly, 25(3), 375-406. http://dx.doi.org/10.2307/3586977.

Hedge, T. (2000). Teaching and learning in the language classroom. Oxford, UK: Oxford University Press.

Holliday, A. (1994). Appropriate methodology and social context. Cambridge, UK: Cambridge University Press.

Johnson, K., \& Golombek, P. (2011). The transformative power of narrative in second language teacher education. TESOL Quarterly, 45(3), 486-509.

Khatib, M., Rezaei, S., \& Derakhshan, A. (2011). Literature in the EFL/ESL classroom. English Language Teaching, 4(1), 201-208. http://dx.doi.org/10.5539/elt.v4n1p201.

Kvale, S. (2007). Doing interviews. London, UK: Sage.

McRae, J. (1991). Literature with a small "l”. London,UK: MacMillan.

Montgomery, M., Durant, A., Fabb, N., Furniss, T., \& Mills, S. (2000). W ays of reading: Advanced reading skills for students of English literature. London, UK: Routledge.

Ondaatje, M. (1993). The English patient. New York, NY: Vintage.

Rosenblatt, L. (1985). The transactional theory of literary work: Implications for research. In C. R. Cooper (Ed.), Researching response to literature and the teaching of literature: Points of departure (pp. 33-53). Norwood, NJ: Ablex.

Shen, M.-Y. (2009). Reading-writing connection for EFL college learners' literacy development. The Asian EFL Journal, 11(1), 89-108.

Spolsky, E. (1989). I come to bury Caesar, not to praise him: Teaching resisting reading. ELT Journal 43(3), 173-179. http://dx.doi.org/10.1093/elt/43.3.173.

Thornbury, S. (1991). Watching the whites of their eyes: The use of teaching-practice logs. ELT Journal, 45(2), 140-146. http://dx.doi.org/10.1093/elt/45.2.140. 
Van, T. T. M. (2009). The relevance of literary analysis to teaching literature in the EFL classroom. English Teaching Forum, 47(3), 2-9.

Wallace, C. (1995). Reading with a suspicious eye: Critical reading in the foreign language classroom. In G. Cook \& B. Seidlhofer, (Eds.), Principles and practice in applied linguistics: Studies in bonour of H. G. Widdowson (pp. 335-347). Oxford, UK: Oxford University Press.

Wallace, C. (2005). Critical reading in language education. Basingstoke, UK: Palgrave MacMillan.

\section{The Authors}

Ornella Ochoa Delarriva holds a BA in English Language Teaching from Universidad Nacional de La Pampa, Argentina. She teaches English and Portuguese in the private sector. She is about to start Translation Studies at Universidad Nacional de Córdoba, Argentina.

Enrique Alejandro Basabe is a lecturer in the Department of Foreign Languages at Universidad Nacional de La Pampa, Argentina. He holds a PhD in Education from Southern Illinois University (USA) and an MA in British Cultural Studies from Warwick University (UK). 


\section{Appendix 1: Guidelines for Writing a Reading Log (Carlisle, 2000, p. 14)}

While you are reading the book write down all the things that go on in your head in a "stream of consciousness" style. As you read, you will be making a record of images, associations, feelings, thoughts, judgments, etc. You will probably find that this record will contain:

Questions that you ask yourself about characters and events as you read (answer these yourself when you can).

Memories from your own experience, provoked by the reading.

Guesses about how you think the story will develop, and why.

Reflections on striking moments and ideas in the book.

Comparisons between how you behave and how the characters in the novel are behaving.

Thoughts and feelings about characters and events.

Comments on how the story is being told. For example, any words and phrases or even whole passages that make an impression on you, or motifs which you notice the author keeps using.

Connections to other texts, ideas, and courses.

An outline of the chapter, no longer than a paragraph.

Please, date each entry, and note the time and place, as well as the mood you are in while reading.

Please note the page number you are reading when you make an entry.

Please take pleasure and pride in your log.

Please do not try to rewrite the book. 


\section{Appendix 2: \\ Lesson Plan for a Discussion of Katherine Clifton in Ondaatje's (1993) The English Patient}

\begin{tabular}{|c|c|}
\hline Class & $\begin{array}{l}\text { Adult students from the ages of twenty to twenty-three. Some } \\
\text { of them participate very actively. }\end{array}$ \\
\hline Language level & Advanced \\
\hline Subject, course, or seminar & English Literature II \\
\hline Number of students & Twenty \\
\hline Text & $\begin{array}{l}\text { The English Patient by Michael Ondaatje (1993). It was agreed } \\
\text { upon by the professor and I. Personally I really liked the novel } \\
\text { and found the secondary character Katherine especially rich. }\end{array}$ \\
\hline Aims & $\begin{array}{l}\text { - To learn more about the character Katherine Clifton. } \\
\text { - To discuss some themes related to her. } \\
\text { - To debate the ending of her relationship with the English } \\
\text { patient. }\end{array}$ \\
\hline Approach & $\begin{array}{l}\text { Language Model: Students will be free to express their feelings } \\
\text { and ideas as long as they can support them with the text. } \\
\text { Students can derive meanings and interpretations by heeding } \\
\text { the author's chosen words and structures. } \\
\text { Personal Growth Model: One of the activities is a } \\
\text { reader-response one, in which students will be encouraged to } \\
\text { talk about their feelings, impressions, and opinions. They can } \\
\text { also relate literature to their own experiences. }\end{array}$ \\
\hline Activities & $\begin{array}{l}\text { 1. Warm-up: Presentation of character by teacher. (T-SS) } \\
\left(10^{\prime}\right) \\
\text { 2. Vocabulary/comprehension: Students will be given topics } \\
\text { and/or themes on paper to analyze in groups. During the } \\
\text { small group activity, the teacher visits each group for a } \\
\text { short period of time and assists or observes the discussion, } \\
\text { depending on the situation. (S-S) }\left(10^{\prime}\right)\end{array}$ \\
\hline
\end{tabular}




\begin{tabular}{|c|c|}
\hline Activities & $\begin{array}{l}\text { 3. Vocabulary/comprehension: The group will be split in } \\
\text { two. One half will be in favor of the author's judgment of } \\
\text { the character. The other half will be against. Both will have } \\
\text { to look for evidence. The teacher acts as a mediator } \\
\text { between both groups. (S-S. Teacher's intervention) }\left(10^{\prime}\right) \\
\text { 4. Extension: Written reader response. Students will write } \\
\text { their impressions about this character. What they } \\
\text { felt/thought about her, whether they had considered her } \\
\text { as relevant or not, and their current impression about her } \\
\text { after the lesson. (Individual) }\left(10 / 15^{\prime}\right)\end{array}$ \\
\hline Time & Approx. 45/60 min. \\
\hline $\begin{array}{l}\text { Preliminary activities } \\
\text { and/or activities extending } \\
\text { from the lesson }\end{array}$ & $\begin{array}{l}\text { Students will have to pay special attention to Chapter V, which } \\
\text { is dedicated entirely to this character. They will also have to } \\
\text { read up to Chapter VIII, in which the end of the story of the } \\
\text { character is revealed. Teacher will collect the written papers, } \\
\text { correct them, and hand them back the following lesson. }\end{array}$ \\
\hline Evaluation & Oral feedback and written assessment \\
\hline Comments & $\begin{array}{l}\text { I feel anxious because I will teach a class to my own } \\
\text { classmates. I also feel afraid that I can be embarrassed if they } \\
\text { ask me something about the character or the novel that I do } \\
\text { not know well. That is why I think that I should read the part } \\
\text { I am going to teach thoroughly. }\end{array}$ \\
\hline
\end{tabular}

